\title{
THE EFFECT OF ADRENAL STEROIDS ON AEROBIC LACTIC ACID FORMATION IN HUMAN LEUKOCYTES ${ }^{1}$
}

\author{
By SAMUEL P. MARTIN,2 S. N. CHAUDHURI, ${ }^{3}$ R. GREEN, AND \\ GORDON R. MCKINNEY « \\ (From the Departments of Medicine, Bacteriology, and Pharmacology, Duke University School \\ of Medicine, Durham, N. C.)
}

(Submitted for publication March 23, 1953; accepted November 12, 1953)

Cortisone has an influence on the course of infectious diseases, as well as on the intensity of the inflammatory response $(1-3)$. One of the important cells in the antibacterial defense and in the inflammatory response is the polymorphonuclear leukocyte. This cell has a very high production of lactic acid in the presence of oxygen and this rate is not altered significantly by the concentration of oxygen $(4,5)$. The early chemical changes in an area of inflammation such as lowering of $\mathrm{pH}$ are in part due to the aerobic lactic acid production by leukocytes.

The present study was undertaken to determine the effect of active and inactive adrenal steroids on this metabolic characteristic of human leukocytes in vitro. Compound $\mathrm{E}$ and $\mathrm{F}$ were found to inhibit aerobic lactic acid production.

\section{MATERIAL AND METHODS}

The method for collection and preparation of blood has been previously described (4). Healthy donors in the fasting state were used. The blood was collected from the cubital veins into a non-wetting system. All glassware was siliconed (G.E. Silicone SC 77). Heparin (0.04 mg. per ml.) or a cation exchange resin (Dowex50) was used to prevent coagulation. The leukocytes were concentrated by the method previously described (4) in which dextran (intrinsic viscosity 0.46 ) is added to produce a final concentration of 1 per cent. The dextran induced rouleaux formation and rapid sedimentation of red blood cells. After removal of the supernatant plasma containing the leukocytes, the cells were concentrated by centrifugation at $50 \times$ G for 15 minutes. The plasma was decanted and the white cells were resuspended in a sufficient volume of buffered saline (4) with $100 \mathrm{mg}$. per cent glucose to obtain a concentration of 5,000 to 25,000 cells per cu.mm. Cortisone and hydrocortisone

1 This work was supported in part by a Research Grant from the National Institutes of Health, Public Health Service, the Baxter Laboratory, and the Spanel Foundation.

2 Markle Scholar of Medicine.

3 Permanent Address: Indian Institute for Medical Research, Calcutta, India.

- Fellow of the American Cancer Society. were dissolved in concentrations of 0.01 to 10.0 micrograms per $\mathrm{ml}$. Cholesterol, desoxycorticosterone and Reichstein's compound $S^{5}$ in final concentration of 10 to 15 micrograms per $\mathrm{ml}$. were also used. The suspension of leukocytes in buffered saline, with and without the steroids, was distributed into $25 \mathrm{ml}$. siliconed Erlenmeyer flasks which were suspended in a constant water bath at $37^{\circ} \mathrm{C}$. and shaken gently in the horizontal axis at the rate of 10 oscillations per minute. Lactic acid was measured by the technique of Barker and Summerson (6). Measurements of initial lactic acid were made before the cells were placed in the water bath and after four- and six-hour periods of incubation. The values are reported as micromoles of lactate produced by $10,000,000$ cells per hour.

In one group of subjects, the in vitro effect of cholesterol, cortisone, hydrocortisone, desoxycorticosterone, and Reichstein's compound S on lactic acid production was measured. In another group, the effect of cortisone on the production of lactate and the utilization of glucose, oxygen, and glycogen was measured by techniques previously described (4).

\section{RESULTS}

The effect of the various steroids on aerobic production of lactic acid by leukocytes from untreated subjects is presented in Table I. Cortisone and hydrocortisone caused a diminution, while compound $\mathrm{S}$ an increase. Cholesterol had no statistically significant effect at four hours. With hydrocortisone, the change was manifest at four hours and was still evident at six hours. With cortisone, the effect at four hours was slight $(P=<0.05)$ and more marked at six hours. Compound $\mathrm{S}$ produced a significant increase in lactate at four and six hours, while desoxycorticosterone produced a rise at six hours which was of questionable significance $(P=<0.05)$. This was probably due to the limited number of observations. These experiments were carried out with a concentration of 10 micrograms per $\mathrm{ml}$. of steroid. Experiments on lactate production by

5 Obtained through the courtesy of Dr. Augustus Gibson of Merck and Co., Rahway, New Jersey, and Dr. William Haines, The Upjohn Co., Kalamazoo, Michigan. 
TABLE I

The effect of adrenal steroids on aerobic lactate formation *

\begin{tabular}{|c|c|c|c|c|c|}
\hline & $\begin{array}{l}\text { No. of } \\
\text { subjects }\end{array}$ & $\begin{array}{l}0-4 \text { hr. } \\
\text { change }\end{array}$ & Change & $\begin{array}{l}0-6 \mathrm{hr} . \\
\text { change }\end{array}$ & Change \\
\hline $\begin{array}{l}\text { Control } \\
\text { Desoxycorticosterone } \\
\text { Cortisone } \\
\text { Hydrocortisone } \\
\text { Compound S } \\
\text { Cholesterol }\end{array}$ & $\begin{array}{r}30 \\
8 \\
30 \\
16 \\
8 \\
8\end{array}$ & $\begin{array}{l}0.59 \pm 0.04 \\
0.64 \pm 0.09 \\
0.53 \pm 0.09 \\
0.46 \pm 0.03 \\
0.68 \pm 0.05 \\
0.62 \pm 0.04\end{array}$ & $\begin{array}{c}+0.05 \pm 0.02 \\
-0.06 \pm 0.03 \\
-0.10 \pm 0.03 \dagger \\
+0.13 \pm 0.05 \dagger \\
0.02 \pm 0.04\end{array}$ & $\begin{array}{l}0.62 \pm 0.05 \\
0.75 \pm 0.05 \\
0.48 \pm 0.04 \\
0.51 \pm 0.04 \\
0.68 \pm 0.04\end{array}$ & $\begin{array}{l}+0.1 \pm 0.02 \\
-0.18 \pm 0.02 \\
-0.10 \pm 0.02^{*} \\
+0.06 \pm 0.02\end{array}$ \\
\hline
\end{tabular}

* Values are expressed in micromoles of lactic acid per $10,000,000$ cells per hour \pm S.E.

$\dagger$ Indicates probability of $>0.01$.

leukocytes exposed to various concentrations of hydrocortisone are presented in Table II. There was no significant change with 0.1 microgram per $\mathrm{ml}$. This would indicate the minimal effective concentration was between 0.1 and 1.0 microgram per $\mathrm{ml}$. In four trials with broken cells no effect could be noted.

The data on the effect of cortisone on lactate production, and on glucose, glycogen and oxygen utilizations are presented in Table III. There was a diminution of lactate production at four and six hours. The former was of questionable significance and the latter was highly significant. The utilization of glucose was lowered at four and six hours. There was no significant change in oxygen and glycogen utilization. Disruption of the cells by grinding with alumina gel blocked the effect of cortisone and hydrocortisone.

\section{DISCUSSION}

These data indicate that some of the adrenal steroids have a direct effect on human leukocytes in vitro. The effect of cortisone was diminution in aerobic lactate production and in glucose utilization. The effect was seen only in intact cells which had been handled with care to prevent injury of cell surfaces. The cellular site of action of the steroids in their effect on lactate production is unknown. Preliminary data would indicate that part of the lactate may be produced through an enzymatic mechanism other than lactic dehydrogenase. This interpretation is based on the lack of complete inhibition of lactate production by oxamic acid. Previous work by Hakala, Glaid, and Schwert (7) has shown oxamic acid to be a specific inhibitor of lactic dehydrogenase. With final concentrations as high as $0.02 \mathrm{M}$ there is less than 40 per cent inhibition. Leukocytes show a high glyoxylase activity and this may account for the remainder of the lactic acid. Glutathione in excess $(0.005 \mathrm{M})$ markedly diminishes lactic acid production $(8,9)$. Since lactic dehydrogenase would seem to account for only a part of the lactate produced by the polymorphonuclear leukocyte, the alteration induced by cortisone could arise from either its effect on pyruvate production or at another site, such as glucose absorption or utilization. Previous work has indicated a close correlation between glucose utilization, glucose concentration, and lactate production by the leukocyte (10). Since the hormones have no effect on broken cells, it would seem that the mode of action is related to the integrative behavior of the cell rather than to the mechanisms of terminal respiration.

The lack of alteration in oxygen utilization despite changes in lactate production cannot be accounted for in the present experiments. Previous studies with human leukocytes have shown

TABLE II

The effect of varying quantities of hydrocortisone on lactate production by human leukocytes in vitro *

\begin{tabular}{lccc}
\hline \hline $\begin{array}{l}\text { Concentration of } \\
\text { hydrocortisone } \\
\text { Micrograms } / \text { ml. }\end{array}$ & 5 & 1 & 0.1 \\
\hline $\begin{array}{l}\text { Change micromoles/ } \\
10 \text { million cells/hr. }\end{array}$ & $-0.08 \pm 0.03$ & $-0.08 \pm 0.02$ & $-.004 \pm 0.02$ \\
\hline
\end{tabular}

* Studies were carried out at 4 hours. Values are reported as micromoles change over control. Values represent ten subjects in each determination. 
TABLE III

The effect of cortisone on metabolism of human leukocytes expressed as micromoles per 10 million cells per hour

\begin{tabular}{lcccccc}
\hline \hline & & \multicolumn{2}{c}{ Control } & & \multicolumn{2}{c}{ Compound E } \\
\cline { 2 - 5 } & $\begin{array}{c}\text { No. of } \\
\text { subjects }\end{array}$ & $0-4 \mathrm{Hr}$. & $0-6 \mathrm{Hr}$. & & $0-4 \mathrm{Hr}$. & $0-6 \mathrm{Hr}$. \\
\hline Lactic acid & 30 & $+0.59 \pm 0.04$ & $+0.62 \pm 0.05$ & & $+0.53 \pm 0.09$ & $\pm 0.48 \pm 0.04^{*}$ \\
Glucose & 30 & $-0.205 \pm 0.02$ & $-0.106 \pm 0.02$ & & $-0.150 \pm 0.017^{*}$ & $-0.070 \pm 0.016^{*}$ \\
Oxygen & 7 & $-0.178 \pm 0.04$ & $-0.139 \pm 0.030$ & & $-0.168 \pm 0.03$ & $-0.127 \pm 0.03$ \\
Glycogen & 5 & & -0.007 & & -0.007 \\
\hline
\end{tabular}

* Indicates probability of $>0.01$

10 Micrograms of Compound E per ml.

a reciprocal relationship between lactate production and glucose utilization on the addition of glucose or on cell injury. The present experiments may indicate a site of action of the hormone not related to the factors controlling oxygen uptake.

The effective levels in these experiments were found to lie between 1.00 and 0.1 micrograms per $\mathrm{ml}$. Nelson, Sandberg, Palmer, and Tyler (11) found that $200 \mathrm{mg}$. of compound $\mathrm{F}$ given orally produced a blood level of 0.60 micrograms per $\mathrm{ml}$. This level was associated with marked change in polymorphonuclear cell count. This is in the same range as the present experiments.

The effect of compound $S$ is the same as the response noted on injury (4). It may be a pharmacological effect or may be due to some factor present in the material such as pyrogen contamination (12). Selye states that desoxycorticosterone and compound $S$ have a prophlogistic effect (13).

The relation of the antiphlogistic and metabolic effect of cortisone and hydrocortisone is not known. The former has been attributed to the action of these agents on the blood vessels (14). The metabolic effects noted here may also be related to the anti-inflammatory action. This alteration in the leukocyte metabolism would result in a slowing of lactic acid production, less change in $\mathrm{pH}$ in the area of inflammation, and possibly longer survival of cells. These factors could be manifested by a slow and abnormal evolution of the inflammatory reaction.

\section{SUMMARY}

Cortisone and hydrocortisone have a direct effect on human leukocytes. These hormones cause diminution in production of lactic acid. Oxygen utilization is not altered. It is postulated that these metabolic alterations may play a role in the antiphlogistic effects of adrenal steroids.

\section{REFERENCES}

1. Dougherty, T. F., and Schneebeli, G. L., Role of cortisone in regulation of inflammation. Proc. Soc. Exper. Biol. \& Med., 1950, 75, 854.

2. Mogabgab, W. J. and Thomas, L., The effects of cortisone on bacterial infection. Group A hemolytic streptococcal infection in rabbits. J. Lab. \& Clin. Med., 1952, 39, 271.

3. Michael, M., Jr., and Wharton, C. M., Delay of the early inflammatory response by cortisone. Proc. Soc. Exper. Biol. \& Med., 1951, 76, 754.

4. McKinney, G. R., Martin, S. P., Rundles, R. W., and Green, $R$., The respiratory and glycolytic activity of human leukocytes in vitro. J. Appl. Physiol., 1953, 5, 335.

5. Kempner, W., The nature of leukemic blood cells as determined by their metabolism. J. Clin. Invest., 1939, 18, 291.

6. Barker, S. B., and Summerson, W. H., The colorimetric determination of lactic acid in biological material. J. Biol. Chem., 1941, 138, 535.

7. Hakala, M., Glaid, A. J., and Schwert, G. W., Kinetics and specificity of lactic dehydrogenase. Federation Proc., 1953, 12, 213.

8. McKinney, G. R., Glyoxalase activity in human leukocytes. Arch. Biochem., In Press.

9. McKinney, G. R., Martin, S. P., and Green, R., Unpublished observations.

10. Martin, S. P., McKinney, G. R., Green, R., and Becker, C., The influence of glucose, fructose, and insulin on the metabolism of leukocytes of healthy and diabetic subjects. J. Clin. Invest., 1953, 32, 1171.

11. Nelson, D. H., Sandberg, A. A., Palmer, J. G., and Tyler, F. H., Blood levels of 17-hydroxycorticosteroids following the administration of adrenal steroids and their relation to levels of circulating leukocytes. J. Clin. Invest., 1952, 31, 843.

12. Martin, S. P., Chaudhuri, S. N., Green, R., and McKinney, G. R., The effect of bacterial products and hormones on human leukocytes. Clin. Research Proc., 1953, 1, 47.

13. Selye, H., The diseases of adaptation: Introductory remarks. Rec. Prog. Horm. Res., 1953, 8, 117.

14. Ebert, R. H., and Barclay, W. R., Changes in connective tissue reaction induced by cortisone. Ann. Int. Med., 1952, 37, 506. 